\title{
Evaluating the Moderating Role of Work-Life Balance on the Effect of Job Stress on Job Satisfaction
}

\author{
Melis Attar1 $\odot$, Vural Çağlıyan2 $\odot$, Aleem Abdul-Kareem ${ }^{\circledR}$
}

\begin{abstract}
Work has occupied an essential place in human life, and this has caused many employees to spend a substantial amount of their time at workplaces. The purpose of this study is to assess the moderating role of work-life balance on the effect of job stress on employees' job satisfaction. A survey method is used to collect the necessary data for this research. A total of 308 respondents from 90 manufacturing SMEs operating in Konya took part in the study. The data gathered are analyzed using SPSS 23 program and Hayes PROCESS macro v.3.4.1. The results of the analyses reveal a statistically significant negative effect of job stress and positive effect of work-life balance on job satisfaction. Moreover, work-life balance is found not to have a moderating role on the effect of job stress on job satisfaction. It is recommended that policy makers and managers of SMEs need to institute stress management techniques that have the propensity of reducing the negative consequences of job stress while maximizing its merits, as well as formulating strategies that will enable employees to have a balance between their personal and work lives.
\end{abstract}

\section{Keywords}

Work-life balance, Job stress, Job satisfaction, Moderating role, SMEs

\section{Introduction}

Job stress and work-life balance (WLB) are significant factors with the potential of determining the level of employees' job satisfaction in an organization. In view of the fact that the kinds of job employees do and how they do them in an organizational setting have changed drastically, many academicians and practitioners are increasingly becoming aware of the need to give considerable attention and interest to job stress and job satisfaction. Some researchers also have thrown some light on the tendency of high job stress leading to employees' job dissatisfaction and intention to leave the business entity (Fairbrother \& Warn, 2003). Job stress has a number of consequences on both the employee and the organization as a whole, such as

\footnotetext{
1 Corresponding Author: Melis Attar (Asst. Prof. Dr.), Selçuk University, Faculty of Economics and Administrative Sciences, Konya, Turkey. E-mail: melisattar@yahoo.com ORCID: 0000-0002-1299-7552

2 Vural Çağlıyan (Prof. Dr.), Selçuk University, Faculty of Economics and Administrative Sciences, Konya, Turkey. E-mail: vcagliyan@selcuk. edu.tr ORCID: 0000-0002-7964-8840

3 Aleem Abdul-Kareem (Mr.), Selçuk University, Department of Business Administration, Konya, Turkey. E-mail: aleemka1992@gmail.com ORCID: 0000-0003-0667-1254

To cite this article: Attar, M., Cagliyan, V., \& Abdul-Kareem, A. (2020). Evaluating the moderating role of work-life balance on the effect of job stress on job satisfaction. Istanbul Business Research, 49(2), 201-223. http://doi.org/10.26650/ibr.2020.49.0081
} 
affecting the safety, emotional and health status of individual employee. Employees who are highly stressed are most likely to engage in absenteeism, become less productive, dissatisfied and show low job performance. On the other hand, when job stress is properly managed and controlled, it could provide employees with energy and passion to effectively and efficiently execute their tasks (Kenworthy et al., 2014). As changes in business environment are causing stress on employees by altering the nature of jobs that employees have to do in an organization, policy makers shall have to focus their attention on measures to limit or reduce employees' job stress. Proper job design, avoidance of role conflict, unambiguous job goals, effective organizational structure and good superior-employee relationships are some of the measures that can be instituted to curtail the negative consequences of workplace stress. Job satisfaction shall be proposed to be the result of low job stress. As long as employees have lower stress levels, they can have more positive feelings and may end in higher job satisfaction because their jobs are no longer a stress factor in their lives.

In recent times, WLB has received continuous interest and being discussed in both academic and business milieus. Many researchers now center their focus on WLB than work-family conflict to accommodate employees who are not parents but wish to get time for their personal activities. Several people on daily basis formulate schedules to deal with their professional and personal activities and time. Thus, employees are more oriented and working towards having a good fit between their personal lives and professional lives. Even nowadays, some applicants in the course of making job applications consider whether the prospective workplace has WLB programs in place. Organizations that have measures and programs instituted to enable employees have good equilibrium between their work and personal lives are viewed to be better organizations than those without (Mas-Machuca et al., 2016). Employees working in organizations that recognize and ensure that there is a good harmony between career life and personal life, are more productive and satisfied (Greenhaus et al., 2003). When job satisfaction is achieved, employees then develop desirable attitudes and positive feelings towards their work.

This study is the first of its kind to attempt to examine whether there is a moderating role of WLB on the effect of job stress on job satisfaction or not. A survey of the literature indicates that most of the existing studies employed a bivariate approach to examine the relationships between these variables. This study is therefore important to the extent that it does not only fill the gap identified in the literature by introducing WLB as a moderator into the model but also adopts an approach that focuses on the three variables. The structure of the article is as follows; the first section presents a review on job stress, WLB and job satisfaction, accompanied by review of empirical findings on these variables. The next immediate section discusses the methodology of the study in detail. The subsequent section presents analysis and empirical results on the moderating role of WLB on the effect of job stress on job satisfaction. The final section touches on conclusion and managerial implications of the study. 


\section{Review of Literature}

This section entails conceptual review and discussion of empirical findings on the three study variables with an aim of hypothesizing.

\section{Job Stress}

The prevalence of stress among employees has received considerable attention and interest for the past decades. A considerable amount of researchers from diverse fields such as psychology, management, medicine and sociology have made emphatic efforts to understand the nitty-gritty of job stress, its causes, consequences and techniques of managing it (Travers \& Cooper, 1993). Researchers from these fields offer different perspectives and interpretations to the concept of stress and this arguably complicates the subject. Thus, the meaning of stress is different for different people under diverse circumstances. Perhaps, the first and the most concise and clear definition of stress is the one provided by Hans Hugo Bruno Selye (popularly referred to as father of stress). Selye (1973: 692) refers to stress as the unspecific reaction of the body to demands placed upon it. Stress focuses on how our body responds to physical and emotional conditions or events that place demands on it. These circumstances could be internal or external with the propensity of frightening, irritating or stimulating us. Stress takes place as the body makes effort to react to both internal and external stimuli. Stress in itself is not necessarily bad since it has the tendency of resulting in creativity, innovation and entrepreneurship. In the view of Kathirvel (2009) stress is the response exhibited by people as a result of undue pressure or other demands on them. It occurs when people are perturbed that they cannot deal with internal or external force placed on them.

Nowadays, work-related stress or job stress is of major concern among practitioners, employers and researchers. Job stress takes place in the event of an inequality between requirements of work and resources, needs and abilities of employees to fulfill demands on them. When there is a mismatch between people's abilities and the job demands, they tend to show response that can cause stress on them (Leka \& Griffiths, 2003). Job stress encapsulates a sequence of psychological, behavioral and physiological reactions as a result of an ongoing impact of one or more stressors on employees in a business setting (Yan \& Xie, 2016). It describes a person's response to some attributes at workplace that may be physically and psychologically frightening (Jamal, 2005). Job stress poses physical and mental impact on employees and could generate negative/positive feelings on them. Job stress can happen in a diverse range of situations. That is to say that, the causes or sources of job stress is broad in perspective of circumstances. Causes of stress could be broadly categorized into organizational, environmental and individual factors. The focus of this paper is on organizational factors as it talks about stress at workplace. Organizational factors that lead to stress among others include; poor job design, role conflict, goals ambiguity, too much workloads, poor 
organizational structure, poor superior-employee relationship and lack of employees involvement in decision making. Leka and Griffiths (2003) opine that job stress could be worse when employees have less control on their jobs or how they can manage its pressures and when they have the feelings that their superiors and colleague employees give them small assistance towards their jobs.

Job stress has a broad range of effect on both individual employee and the organization. Job stress can result into employee absenteeism, low productivity, sleeplessness, depression, turnover and overall distraction of smooth functioning of the organization. Hussain et al. (2003) indicate that higher stress leads to lesser satisfaction, which results to intentions to quit work. Short-term products of job stress have behavioral and physiological impacts resulting in bad performance on job (Williams et al., 2001). Conversely, the right job stress can offer employees with positive vitality and enthusiasm to properly engage in the job with enhanced efficiency and effectiveness (Kenworthy et al., 2014; Chen et al., 2017). Stress can hardly be avoided or ignored so far as one is still alive and kicking. Even when a person is asleep, the body needs some energy to make sure that the organs function properly. People rather need to focus on how to apply some stress management techniques such as physical exercise, hypnosis, relaxation, meditation and effective time management to curb the negative consequences of stress while maximizing its merits.

\section{Work-Life Balance (WLB)}

WLB is a broader concept in scope and more current in the literature than work-family conflict. The attention of many researchers and organizations is now on WLB so as to accommodate employees who are not parents and do not have responsibilities from dependents but aspire to find time to address their non-earning/personal activities such as learning, entertainment and embarking on trips. Work-family conflict deals with a sort of inter-role conflict that arises due to irreconcilable role pressures emanating from work and family domains (Yildirim \& Aycan, 2008). Whereas, work-family balance characterizes satisfaction, happiness, fulfillment and efficient functioning at work and home with a least amount of role conflict (Clark, 2000).

It is logical for every employee to desire to have a good fit between their personal lives and work lives. Managing work and personal life is challenging and not as simple as it may seem to be. It is not surprising these days to see organizations instituting programs to help employees attain equilibrium between their private lives and professional lives, as doing so enhances employee performance, efficiency, loyalty and satisfaction in both personal and professional lives. As Karthik (2013) indicates, firms can use WLB programs to promote sustainability, decrease turnover and exhaustion level. Hence, putting measures in place to sustain a healthy balance between special and work life gives the chance for long-term benefits. A proper balance between professional and personal life provides a business firm with a 
creative and effective employees (Greenhaus et al., 2003), while variation in the WLB could result in depressed, disgruntled and dissatisfied employees (Kofodimos, 1993).

Although, WLB as a concept has received too much attention and often discussed in recent times, it however, has no universally accepted definition. As Kalliath and Brough (2008) rightly point out that literature on WLB does not entail one obvious definition of the concept and full meaning of the concept is complex to be captured with a simple general measure. It appears that difficulty in getting a clear definition for the concept is due to its broad nature as it merges 'work', 'life' and 'balance'. Nonetheless, some existing definitions for WLB are explored. Dundas (2008) posits that WLB is about how people manage their paid work life and every other thing that is significant to them, such as voluntary activities, community and family issues, personal advancement and recreational activities. In the view of Kalliath and Brough (2008) WLB is how a person perceives work and non-work activities to be in harmony and assist progress in consistent with the person's present life priorities. Though, these two definitions emphasize the need for a harmony between professional activities and personal activities, a line of departure exists between them. The line of distinction between them is anchored on the fact that the latter definition extends its scope to capture the possibility of effective WLB leading to favourable growth and progress in the context of work and or non-work circumstances. Another explanation of WLB worth presenting here is that of Greenhaus et al. (2003), who describe it as the degree to which people are equally involved in and evenly satisfied with their job and family roles. The focus of this definition is on how people can attain equilibrium of satisfaction across multiple life roles. WLB is a desirable but tricky goal to achieve. It refers to the individual's perceptions of how properly work and non-work activities are compatible and are tackled in line with their personal value system, aims and ambitions (Casper et al., 2018). Thus, WLB deals with how personal life interacts or interferes with professional life to result in a good fit between the two. A good equilibrium between the two may be evident in quality of work not being deteriorated and life satisfaction of an individual enhanced. It is also invaluable to point out the fact that WLB is not something static for a long period of time. It is a concept that is dynamic and changes over time based on the circumstances or the needs of persons or business entities.

\section{Job Satisfaction}

Empirical studies and investigation on job satisfaction can be traced back to 1935, where Robert Hoppock has written a groundbreaking book on the topic, followed by an article on job satisfaction of psychologists in 1937. He can well be credited as the pioneer of job satisfaction research. Another early researcher on the topic that comes to mind is Donald E. Super. Super (1939) assessed the link between job satisfaction and occupational level of 273 members of vocational groups in New York City. The deductions drawn from this study assisted and shaped the direction of future researchers on job satisfaction. Since then, several articles examining different facets of job satisfaction have been published (Judge et al., 2001). 
Job satisfaction is a concept that concerns employees, employers and academicians. It is perhaps no wonder job satisfaction continues to receive incessant attention from these three parties, given the positive outcomes likely to result from it. Job satisfaction is basically a desirable feeling people have about their jobs emanating from their assessment of the features of the jobs. People tend to have positive or negative feelings about their work after they evaluate the characteristics of the job. According to Robbins and Judge (2016: 116) a person with less job satisfaction has negative feelings towards his/her job, whereas, a person with greater job satisfaction has positive feelings towards the work. Job satisfaction is a broader concept which is related to all or most attributes of the job and the working environment under which the employees are evaluated, rewarded, fulfilled and satisfied (Weiss, 2002). Some researchers use how employees perceive the rewards received from work done to explain job satisfaction. For instance Daehlen (2008) and Koh and Boo (2001) view the concept as the disparity between the amount of rewards employees receive and the amount they believe is due them. In this scenario, employees' satisfaction with the job is likely to be high if the reward received matches their expectations, values, needs and performance, as well as whether the reward is perceived fair, just and equitable. The nature of the job in general and expectations employees have on their jobs can determine whether a job could be satisfying or dissatisfying (Yiu \& Lee, 2011). Job satisfaction can also be viewed in terms of it being a multidimensional concept encompassing different aspects of the job in relation to working hours, pay, professional opportunities, fringe benefits, organizational practices and relationship with colleague employees and superiors. Thus, job satisfaction is a variety of job facets (Friday \& Friday, 2003). Job satisfaction refers to the general behavior employees have relating to their work. Those who are satisfied with their work exhibit positive attitudes towards their work, whilst those who are not display negative attitudes towards the work (Armstrong, 2006).

Job satisfaction or dissatisfaction has a number of ramifications that need to be given great attention in order to institute measures that will tackle its adverse side. The effect of job satisfaction or dissatisfaction can be looked at from the perspective of workforce or organization as a whole. On the part of employees, the focus is on how job satisfaction or dissatisfaction affects their psychological well-being, whereas, on the organization side, the concern is on how it influences efficient and effective functioning of the business entity. A critical evaluation of literature concerning job satisfaction signals a favorable relationship between job satisfaction and customer satisfaction, job performance and organizational citizenship behavior (Goode \& Moutinho, 1995; Hoffman et al., 2007; Robbins \& Judge, 2016). That is to insinuate that satisfied employees tend to be more productive, perform well on their job, engage in citizenship behavior and increase customer satisfaction. Job dissatisfaction on the other hand causes employees to indulge in counterproductive work behavior such as absenteeism, tardiness, gossiping and turnover. When people dislike or are not satisfied with their work they are inclined to engage in workplace misbehavior or deviant behavior that can potentially harm the 
smooth functioning of the business (Riketta, 2008; Scroggins, 2008; Page \& Vella-Brodrick, 2009). Therefore, employers or managers could center their attention on those factors that have demonstrated to be pleasant to high levels of job satisfaction. These factors encompass providing equitable rewards, allowing for participation in decision making process, providing challenging and scintillating work, good relations and building supportive working environment (Saari \& Judge, 2004).

\section{Review of Empirical Findings on Job Stress, WLB and Job Satisfaction}

In this part, first, empirical review findings for job stress and job satisfaction presented, followed by WLB and job satisfaction and the combined relationship between WLB, job stress and job satisfaction.

Job stress caused as a result of favoritism, cronyism and nepotism in the workplace has the propensity of increasing dissatisfaction among staff in an organization (Arasli \& Tumer, 2008). In a study conducted by Keleş and Findıklı (2016) to determine the effect and correlations among job satisfaction, job stress and intention to leave on employees in insurance sector in Istanbul, a significant negative relationship has found between job stress and job satisfaction. Goswami and Dsilva (2019) have also found negative influence of job stress on job satisfaction of employees working in Mumbai's hospitality sector. In a related research by Ahsan et al. (2009) on 300 academic staff of a public university in Malaysia, job stress is significantly negatively related to job satisfaction.

Business enterprises should offer their employees with WLB facilities to enable them to be more effective and productively perform their duties (Parvin \& Kabir, 2011). Mas-Machuca et al. (2016) have conducted a study on the relationship of WLB with organizational pride and job satisfaction in Spanish pharmaceutical organization and have found WLB to be positively linked to job satisfaction. The results of a study by Hussein et al. (2016) on employees of Northern Rangelands Trust in Kenya have also revealed a strong positive relationship between WLB and job satisfaction. In another study done by Ueda (2012) on 2972 Japanese employees with the main purpose of ascertaining the influence of WLB programs on employee satisfaction, a significant positive effect of WLB programs on employee satisfaction has depicted.

It has been revealed in a study carried out by Saeed \& Farooqi (2014) on 171 university teachers that there exists a relationship between WLB, job stress and job satisfaction. Specifically, the results of the study have showed a moderate positive relationship between WLB and job satisfaction and an insignificant relationship between job stress and job satisfaction. Kanwar et al. (2009) have also conducted a study on 313 respondents from IT and IT enabled services industries in New Delhi with the main aim of ascertaining the effect of WLB and burnout (prolonged job stress) on job satisfaction. The findings of the study reveal a positive 
link between WLB and job satisfaction, while burnout is negatively related to job satisfaction. Also, an empirical research by Kazmi \& Singh (2015) on a sample of 350 police personnel show a significant prediction of WLB and operational stress on job satisfaction. A deduction is made from a survey of the literature that there exists no empirical study about a moderating role of WLB on the effect of job stress on job satisfaction. This prompted the researchers to evaluate whether people with WLB may feel the effect of their job stress reduced in relation with their job satisfaction or not. Moderating role occurs when the size, sign, or strength of the relationship between an independent variable and a dependent variable depends on a third variable or can be predicted by that variable. In that sense, the third variable is considered to be a moderator of the independent variable's effect on the dependent variable or that the moderator and the predictor variable interact in their effect on the outcome variable (Hayes, 2017: 220).

\section{Methodology}

The aim of this study is to establish the moderating role of WLB on the effect of job stress on job satisfaction of employees working in SMEs operating in Büsan Organized Industrial Zone in Konya, Turkey. Specifically, this study is limited to manufacturing SMEs in the area of automotive spare parts with the intention that the number of employees is higher than that of organizations in other sectors and also there is more work load density when compared to others. In order to achieve the research objective, quantitative analyses are employed.

\section{Model and Hypotheses of the Study}

The kind of association between the dependent variable, the moderator and the independent variables is displayed diagrammatically in Figure 1 and 2 below.

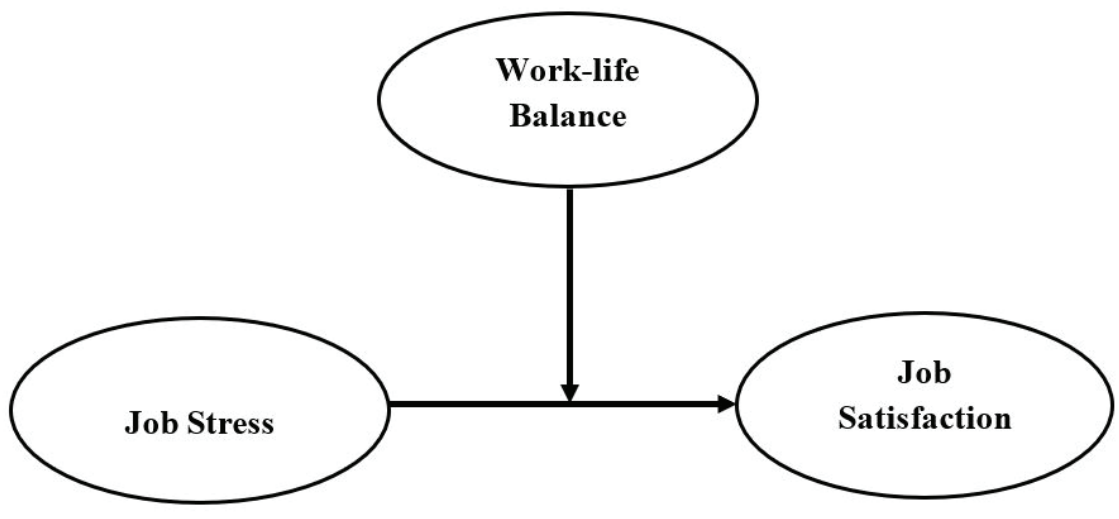

Figure 1. Conceptual model of the study 
Model 1 developed by Hayes (2017: 584) and its statistical structure is used to test the moderator effect. The statistical diagram of the model is presented in Figure 2.

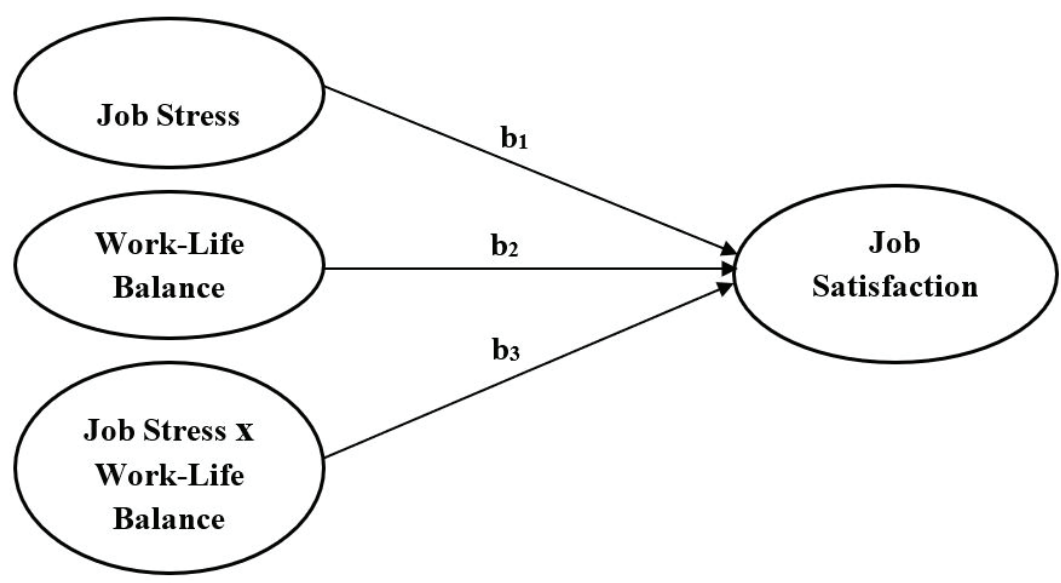

Figure 2. Statistical diagram of the study

Source: Adapted from Hayes (2017)

The proposed conceptual model in Figure 1 and the statistical diagram of the study in Figure 2 are both inspired by Model 1 of Hayes (2017). In view of this, three hypotheses are developed and presented below.

H1: There is a significant negative effect of job stress on job satisfaction.

H2: Work-life balance has a significant positive effect on job satisfaction.

H3: Work-life balance has a moderating role on the effect of job stress on job satisfaction.

\section{Research Population and Sample}

The research population is made up of employees working in automotive spare parts manufacturing SMEs in Büsan Organized Industrial Zone located in Konya. In total, ninety (90) manufacturing SMEs are included in the study. The whole number of people in these SMEs at the time of conducting this research stays at 1240. Information on the number of employees in each enterprise is derived from firms' manuals and face to face interactions. The study sample size is calculated by applying Yamane (1967) sampling formula $\left(n=N /\left(1+\mathrm{Ne}^{2}\right)\right.$, with $95 \%$ confidence interval and 5\% error level. A sample size of 302 is found out to be required size through the application of the formula. So, 308 questionnaires received can be said to have the power to represent the main population. 
In choosing the sample size, both purposive sampling and simple random techniques are used. The former sampling technique is used to choose the sector of focus of the study (Manufacturing SMEs), while the latter is used in selecting the employees who participated in the research. This sector is chosen with the intention that the number of employees is higher than that of other organizations in the area and also, there is more workload density when compared to.

\section{Data Collection Procedures and Measures}

Questionnaires are administered as the main instrument of data collection. Three hundred and fifty (350) questionnaires are distributed to the respondents after an explanation of the aim of the study and how to fill the instrument. There are four main sections in the research questionnaires with a total of 46 questions. The first part is for collecting data on the demographic attributes of the respondents. The second and third parts are dedicated to the predictor variable and the moderator respectively. The last section contains questions concerning the outcome variable. A total of three hundred and eight (308) questionnaires are properly completed and received. This constitutes a total response rate of $88 \%$. The remaining $12 \%$ are either unreturned ones or rejected due to incomplete responses.

A 7-item scale developed by House and Rizzo (1972) and translated into Turkish by Efeoğlu and Özgen (2006) is used to measure job stress. These items are measured using 5 -point Likert type; starting from $1=$ Strongly Disagree to $5=$ Strongly Agree. The work-life balance scale consists of 13 items developed by Fisher (2001) and translated into Turkish Apaydın (2011) is adopted to measure WLB. The 13 items are measured on a 5-point Likert scale; starting from $1=$ Not at all to $5=$ Almost all of the time. The short form of Minnesota Satisfaction Questionnaire (MSQ) designed by Weiss, Dawis, and England (1967) is used to measure job satisfaction. This questionnaire form consists of 20 items and is translated by Baycan (1982) into Turkish. All the 20 items are adapted into the current study and measured on a 5-point Likert type; starting from; 1=Very Dissatisfied to 5=Very Satisfied.

\section{Analysis and Findings}

The data gathered from the participants are analyzed using SPSS 23 program and Hayes PROCESS Macro v.3.4.1.

\section{Demographic Data of Respondents}

The demographic data collected includes gender, age, marital status, educational level, job title and duration of work experience. The results are presented on Table 1. 
Table 1

Demographic Data

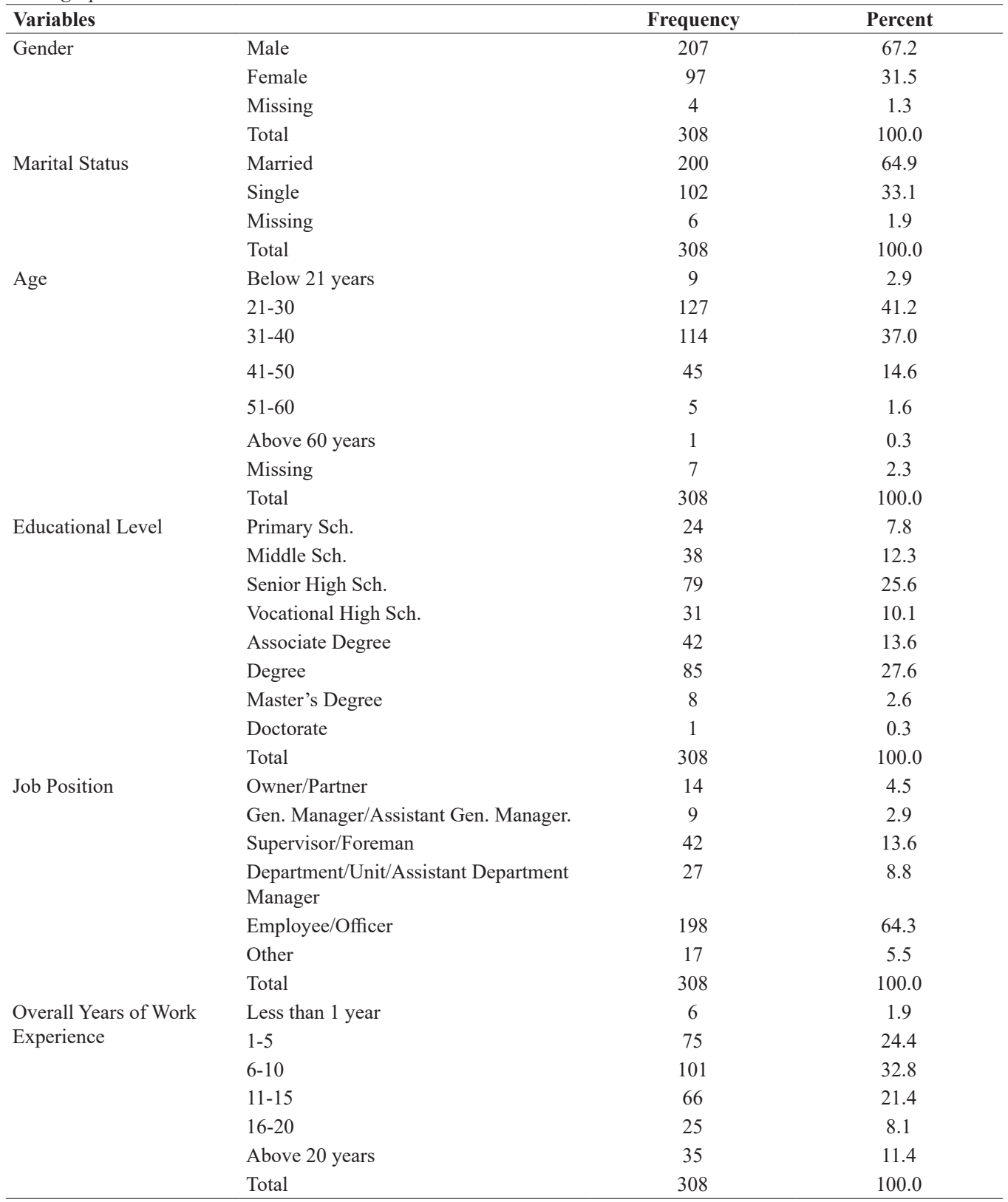

It is obvious from Table 1 that a large portion of the respondents are male representing $67.2 \%$ and $64.9 \%$ of the participants also indicated they are married. In the age group category, majority of the respondents are $21-30$ and $31-40$ age groups with $41.2 \%$ and $37 \%$ respectively. On educational level, greater parts of the participants are bachelors' degree holders and 
senior high school graduates with $27.6 \%$ and $25.6 \%$ respectively. In terms of job position, majority $(64.3 \%)$ of them indicated they are employees, followed by $13.6 \%$ of them occupying the position of a supervisor/foreman. A large percentage $(32.8 \%)$ of the participants has total working experience ranging from 6-10 years.

\section{Assessment of Scale Reliability}

The scales used in this study are subjected to reliability and validity tests by previous researchers (Weiss, et al., 1967; House \& Rizzo, 1972; Baycan, 1982; Fisher, 2001; Apaydın, 2011). In an attempt to find out how reliable and valid these scales are in the case of this study too; the necessary reliability and validity tests are performed. The overall reliability result of all the items used in this study in their respective scales is presented on Table 2 below.

Table 2

Reliability Test

\begin{tabular}{lccc}
\hline Scale & $\begin{array}{c}\text { Measurement } \\
\text { Interval }\end{array}$ & $\begin{array}{c}\text { Number of } \\
\text { Items }\end{array}$ & $\begin{array}{c}\text { Cronbach Alpha } \\
\text { Value }\end{array}$ \\
\hline Job Stress & & 7 & 0.835 \\
Dimension 1 & 5-point Scale & 3 & 0.803 \\
Dimension 2 & & 3 & 0.788 \\
Work-Life Balance & & 13 & 0.932 \\
Dimension 1 & 5-point Scale & 4 & 0.931 \\
Dimension 2 & & 5 & 0.926 \\
Dimension 3 & & 3 & 0.867 \\
Job Satisfaction & & 20 & 0.896 \\
Dimension 1 & 5-point Scale & 7 & 0.850 \\
Dimension 2 & & 7 & 0.893 \\
Dimension 3 & & 5 & 0.851 \\
\hline
\end{tabular}

Notes: (i) In the job stress scale, the $7^{\text {th }}$ item "I often 'take my job home with me' in the sense that I think about it when doing other things" has been removed. The scale is evaluated with a total of 6 items. (ii) The item "My job gives me energy to pursue personal activities" has been eliminated from the WLB scale. The scale is evaluated with a total of 12 items. (iii) In the job satisfaction scale, the $15^{\text {th }}$ item "The freedom to use my own judgment" has been removed from the scale. The scale is evaluated with a total of 19 items. These items are removed from their respective scales due to the fact that their corrected-item total correlations are less than 0.5. These eliminated items are also not included in all subsequent analyses of this study.

The above Table 2 demonstrates that the Cronbach alpha values of all the scales used are beyond the ideal point of 0.7 . Therefore, it can be said that the internal stability and consistency of the scales used are adequate.

\section{Validity Test and Descriptive Statistics}

For the purpose of determining the validity of the scales used, a varimax rotation principal component factor analysis is applied. The results of factor analysis for job stress are presented on Table 3 below. 
Table 3

Factor Analysis of Job Stress Scale

\begin{tabular}{llcc}
\hline & Scale Items & $\mathbf{1}$ & $\mathbf{2}$ \\
\hline Job Tension & My job tends to directly affect my health. & 0.839 \\
& I work under a great deal of tension. & 0.826 \\
I feel fidgety or nervous because of my job. & 0.772 & 0.632 \\
& If I had a different job, my health would probably improve. & 0.852 \\
& Problems associated with work have kept me awake at night. & 0.874 \\
& I feel nervous before attending meetings held in my company. & $\mathbf{3 . 2 9 8}$ & $\mathbf{1 . 0 2 4}$ \\
& Eigenvalue & $\mathbf{3 7 . 7 7 6}$ & $\mathbf{3 4 . 7 5 0}$ \\
& Variance Explained (\%) & $\mathbf{0 . 8 0 3}$ & $\mathbf{0 . 7 8 8}$
\end{tabular}

Note: (i) Varimax rotation principal component factor analysis (ii) KMO: 0.809, Bartlett test $=710.825$, df $=15$; $\mathrm{P}<0.001$

As displayed on Table 3, the results of the principal component factor analysis reveal two dimensions of job stress. Dimension 1 explains a total variance of $37.776 \%$, dimension 2 explains a total variance of $34.750 \%$ and total variance on job stress that can be explained by these two dimensions is $72.026 \%$. The eigenvalues of the items are greater than 1 and all factor loadings are greater than 0.50 . However, the dimensions of the factor structure (job tension and work anxiety) found on the job stress scale in this study differs from that of some others (Mengenci, 2015; Deveci \& Avc1kurt, 2017), that found it as a one-factor structure.

Table 4 below presents descriptive evaluation of the participants' job stress level.

Table 4

Respondents View on their Job Stress (Jstr) Level

\begin{tabular}{lcc}
\hline Scale Items & Mean & Std. Deviation \\
\hline Jstr_1 & 3.12 & 1.25 \\
Jstr_2 & 2.88 & 1.22 \\
Jstr_3 & 2.80 & 1.15 \\
Job Tension & $\mathbf{2 . 9 3}$ & $\mathbf{1 . 0 2}$ \\
Jstr_4 & 2.87 & 1.17 \\
Jstr_5 & 3.23 & 1.29 \\
Jstr_6 & 3.04 & 1.24 \\
Work Anxiety & $\mathbf{3 . 0 5}$ & $\mathbf{1 . 0 4}$ \\
Total Job Stress & $\mathbf{2 . 9 9}$ & $\mathbf{0 . 9 0 2}$ \\
\hline
\end{tabular}

Note: (i) $n=308$ (ii) Based on Friedman's two-way Anova test $\chi^{2}=120,908 ; p<0,001$, the results are statistically significant.

The above Table 4 shows the average value (mean) of responses to the questions on the job stress scale. When the table is examined, the dimensions of job stress; job tension and work anxiety have means of 2.93 and 3.05 respectively. The overall job stress mean is 2.99 . This result implies that the respondents' level of job stress is moderate or average on a 5-point likert scale.

The scale used to measure WLB is also subjected to a varimax rotation principal component factor analysis. The results of factor analysis on this scale are shown on Table 5 below. 
Table 5

Factor Analysis of Work-Life Balance Scale

\begin{tabular}{|c|c|c|c|c|}
\hline & Scale Items & 1 & 2 & 3 \\
\hline & $\begin{array}{l}\text { I have difficulty getting my work done because I am preoccupied } \\
\text { with personal matters. }\end{array}$ & 0.753 & & \\
\hline$\stackrel{5}{3}$ & My personal life drains me of the energy I need to do my job. & 0.775 & & \\
\hline 0 & $\begin{array}{l}\text { I am too tired to be effective at work because of things I have going } \\
\text { on in my personal life }\end{array}$ & 0.779 & & \\
\hline 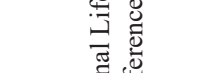 & $\begin{array}{l}\text { My work suffers because of everything going on in my personal } \\
\text { life. }\end{array}$ & 0.812 & & \\
\hline 这 & $\begin{array}{l}\text { When I am at work, I worry about things I need to do outside of } \\
\text { work. }\end{array}$ & 0.793 & & \\
\hline & $\begin{array}{l}\text { I often neglect my personal needs because of the demands of my } \\
\text { work. }\end{array}$ & & 0.804 & \\
\hline 巳゙ & $\begin{array}{l}\text { I have to miss out on important personal activities because of my } \\
\text { work. }\end{array}$ & & 0.827 & \\
\hline 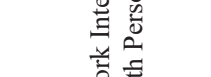 & $\begin{array}{l}\text { My job makes it difficult to maintain the kind of personal life I } \\
\text { would like. }\end{array}$ & & 0.818 & \\
\hline 3 & Put personal life on hold for work. & & 0.758 & \\
\hline 牙 & Better mood at work because of personal life. & & & 0.850 \\
\hline 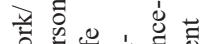 & Because of my job, I am in a better mood at home. & & & 0.821 \\
\hline 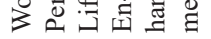 & My personal life gives me the energy to do my job. & & & 0.750 \\
\hline & Eigenvalue & 7.452 & 1.144 & 1.045 \\
\hline & Variance Explained (\%) & 31.728 & 27.969 & 20.649 \\
\hline & Cronbach Alpha & 0.931 & 0.926 & 0.867 \\
\hline & Total Variance (\%) 80.346 & & & \\
\hline
\end{tabular}

Note: (i) Varimax rotation principal component factor analysis (ii) KMO: 0.929, Bartlett test $=3135.192, \mathrm{df}=66$; $\mathrm{P}<0.001$

As shown in Table 5, the results of the factor analysis corroborate the three dimensions of WLB. Dimension 1 explains a total variance of $31.728 \%$, dimension 2 explains a total variance of $27.969 \%$, dimension 3 explains a total variance of $20.649 \%$, and total variance on WLB that can be explained by these three dimensions is $80.346 \%$. All the factor loadings are very well beyond 0.50 and their eigenvalues are greater than 1 . The three-factor structure found on this scale in the present study is similar to what is discovered by other studies (Fisher, 2001; Hayman, 2005; Erben \& Ötken, 2014).

A descriptive evaluation of the participants' WLB is presented on Table 6.

Table 6 above shows the average of the responses to the questions on the WLB scale. When the table is examined, the dimensions of WLB; work interference with personal life (3.26), personal life interference with work (2.72) and work/personal life enhancement (3.29) is seen. In general, it can be said that the total WLB of the participants is above average level on a 5-point likert scale as shown by the overall mean of 3.13 .

A varimax rotation principal component factor analysis is also applied on the job satisfaction scale. The findings on this scale are presented on Table 7 below. 
Table 6

Respondents View on their Work-Life Balance (WLB) Level

\begin{tabular}{lcc}
\hline Scale Items & Mean & Std. Deviation \\
\hline WLB_1 & 3.22 & 1.37 \\
WLB_2 & 3.28 & 1.35 \\
WLB_3 & 3.10 & 1.36 \\
WLB_4 & 3.09 & 1.38 \\
Work Interference with Personal Life & $\mathbf{3 . 2 6}$ & $\mathbf{1 . 2 9}$ \\
WLB_5 & 2.79 & 1.35 \\
WLB_6 & 2.89 & 1.43 \\
WLB_7 & 2.79 & 1.44 \\
WLB_8 & 2.61 & 1.43 \\
WLB_9 & 2.68 & 1.38 \\
Personal Life Interference with Work & $\mathbf{2 . 7 2}$ & $\mathbf{1 . 2 8}$ \\
WLB_10 & 3.29 & 1.34 \\
WLB_11 & 3.14 & 1.39 \\
WLB_12 & 3.49 \\
Work/Personal Life Enhancement & $\mathbf{3 . 2 9}$ & 1.40 \\
Total Work-Life Balance & $\mathbf{3 . 1 3}$ & $\mathbf{1 . 2 5}$
\end{tabular}

Note: (i) $n=308$ (ii) According to the Friedman's two-way Anova test $\chi^{2}=388,161 ; \mathrm{p}<0,001$, the results are statistically significant.

Table 7

Factor Analysis of Job Satisfaction Scale

\begin{tabular}{|c|c|c|c|c|}
\hline \multicolumn{2}{|c|}{ Scale Items } & 1 & 2 & 3 \\
\hline \multirow{7}{*}{ 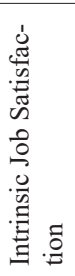 } & The way my job provides for steady employment. & 0.749 & & \\
\hline & The chance to do things for other people. & 0.655 & & \\
\hline & The chance to tell people what to do. & 0.743 & & \\
\hline & The chance to do something that makes use of my abilities & 0.787 & & \\
\hline & The way company policies are put into practice & 0.801 & & \\
\hline & My pay and the amount of work I do. & 0.757 & & \\
\hline & The chances for advancement on this job. & 0.745 & & \\
\hline \multirow{7}{*}{ 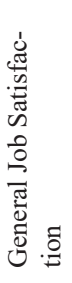 } & Being able to keep busy all the time. & & 0.790 & \\
\hline & The chance to work alone on the job. & & 0.735 & \\
\hline & The chance to do different things from time to time. & & 0.636 & \\
\hline & The chance to be "somebody" in the community. & & 0.730 & \\
\hline & The way my boss handles his/her workers. & & 0.748 & \\
\hline & The competence of my supervisor in making decisions. & & 0.677 & \\
\hline & Being able to do things that don't go against my conscience. & & 0.630 & \\
\hline \multirow{9}{*}{ 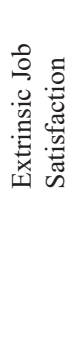 } & The chance to try my own methods of doing the job & & & 0.718 \\
\hline & The working conditions. & & & 0.709 \\
\hline & The way my co-workers get along with each other & & & 0.784 \\
\hline & The praise I get for doing a good job & & & 0.780 \\
\hline & The feeling of accomplishment I get from the job. & & & 0.715 \\
\hline & Eigenvalue & 6.726 & 2.801 & 1.695 \\
\hline & Variance Explained (\%) & 22.576 & 19.740 & 16.742 \\
\hline & Cronbach Alpha & 0.850 & 0.893 & 0.851 \\
\hline & Total Variance $(\%)$ & & 59.058 & \\
\hline
\end{tabular}

Note: (i) Varimax rotation principal component factor analysis (ii) KMO: 0.879, Bartlett test $=2921.026$, $\mathrm{df}=171 ; \mathrm{P}<0.001$ 
As shown on Table 7, three dimensions of job satisfaction are revealed from the principal component factor analysis. Dimension 1 explains a total variance of $22.576 \%$, dimension 2 explains a total variance of $19.740 \%$, dimension 3 explains a total variance of $16.742 \%$, and total variance on job satisfaction that can be explained by these three dimensions is $59.058 \%$. The three-factor structure discovered in this study concurs with that of Tan \& Hawkins (2000) who also reports a 3-factor structure of the scale.

Table 8 below presents a descriptive assessment of the respondents' job satisfaction level.

Table 8

Participants View on their Job Satisfaction (Jsat) Level

\begin{tabular}{|c|c|c|}
\hline Scale Items & Mean & Std. Deviation \\
\hline Jsat_1 & 3.47 & 0.99 \\
\hline Jsat_2 & 3.53 & 0.98 \\
\hline Jsat_3 & 3.66 & 1.01 \\
\hline Jsat_4 & 3.69 & 1.00 \\
\hline Jsat_5 & 3.53 & 1.05 \\
\hline Jsat_6 & 3.46 & 1.04 \\
\hline Jsat_7 & 3.49 & 0.99 \\
\hline General Job Satisfaction & 3.55 & 0.73 \\
\hline Jsat_8 & 3.60 & 0.95 \\
\hline Jsat_9 & 3.72 & 0.93 \\
\hline Jsat_10 & 3.63 & 0.95 \\
\hline Jsat_11 & 3.75 & 1.01 \\
\hline Jsat_12 & 3.46 & 1.09 \\
\hline Jsat_13 & 3.32 & 1.14 \\
\hline Jsat_14 & 3.36 & 1.13 \\
\hline Intrinsic Job Satisfaction & 3.55 & 0.80 \\
\hline Jsat_16 & 3.70 & 1.00 \\
\hline Jsat_17 & 3.40 & 1.13 \\
\hline Jsat_18 & 3.63 & 1.14 \\
\hline Jsat_19 & 3.51 & 1.12 \\
\hline Jsat_20 & 3.84 & 1.06 \\
\hline Extrinsic Job Satisfaction & 3.62 & 0.86 \\
\hline Total Job Satisfaction & 3.57 & 0.61 \\
\hline
\end{tabular}

Note: (i) $n=308$ (ii) Based on Friedman's two-way Anova test $\chi^{2}=196,899$; $p<0,001$, the results are statistically significant.

Table 8 above shows the average value of responses given to the questions on job satisfaction scale. When the table is examined, the dimensions of job satisfaction; general job satisfaction, intrinsic job satisfaction and extrinsic job satisfaction have means of $3.55,3.55$ and 3.62 respectively. The overall job satisfaction mean is 3.57 . This indicates that the respondents' level of job satisfaction is above average on a 5-point likert scale. 


\section{Correlation Analysis}

The nature of relationship that exists among the study variables is established through Pearson's correlation coefficient. The results of the correlation analysis are displayed on table 9.

Table 9

Correlation Results

\begin{tabular}{lccc}
\hline Variable & Job Stress & Work-Life Balance & Job Satisfaction \\
\hline Job Stress & 1 & & \\
Work-Life Balance & -0.041 & 1 & 1 \\
& 0.469 & $0.502^{* *}$ & 0.000 \\
\hline
\end{tabular}

** Cor. is significant at 0.01 level (2-tailed). $\mathrm{n}=308$

It is apparent from correlation matrix above that there is a statistically insignificant weak negative relationship between job stress and WLB. Results of previous studies support the negative relationship between these two variables (see Sirajunisa \& Panchanatham, 2010; Bell, et al., 2012). Furthermore, a statistically significant low negative relationship between job stress and job satisfaction is found. This finding concurs with those in the literature (see Ahsan et al., 2009; Keleş \& Fındıkl1, 2016). It can also be deduced from the same table that the relationship between WLB and job satisfaction is a statistically significant moderate positive relationship. This result shows a good congruence with existing findings in the literature (see Kanwar, et al., 2009; Saeed \& Farooqi, 2014; Mas-Machuca, et al., 2016).

\section{Findings Relating to the Hypotheses of the Research}

This section presents inferential statistics on hypotheses testing. In an attempt to determine the effect of job stress on job satisfaction, the following linear regression analysis is carried out. Prior to this, the regression model below is proposed.

Where $b_{0}$ is the constant value and $\epsilon$ is the error term, which is valid in classical regression assumptions.

Table 10

Regression Results of the Effect of Job Stress on Job Satisfaction

\begin{tabular}{lcccccc}
\hline Dependent Variable & Adjusted R & Independent Variable & B & Std. Error & t & F \\
\hline \multirow{2}{*}{ Job Satisfaction } & \multirow{2}{*}{0.059} & Constant & 4.074 & 0.117 & $34.722^{*}$ & $20.367^{*}$ \\
& & Job Stress & -0.170 & 0.038 & $-4.513^{*}$ & \\
\hline
\end{tabular}

Note: ${ }^{*}<<0.001$.

From Table 10 above, an adjusted $\mathrm{R}^{2}$ of 0.059 implies that $5.9 \%$ of the variances in job satisfaction can be explained by job stress. An F value (degree of significance of the regression model) of 20.367 , t-value of -4.513 , beta value of -0.170 and a p-value of 0.00 clearly indicate that the model is significant. These results support the first hypothesis which states that "There is a significant negative effect of job stress on job satisfaction". Consequently, H1 
is accepted based on the results. This result coincides with findings of other researchers in the literature (Ahsan et al., 2009; Bemana et al., 2013; Goswami \& Dsilva, 2019).

The following linear regression analysis is carried out to assess the effect of WLB on job satisfaction. The regression model below is first proposed.

Table 11

Regression Results for the Effect of WLB on Job Satisfaction

\begin{tabular}{lcccccc}
\hline Dependent Variable & Adjusted R & Independent Variable & B & Std. Error & t & F \\
\hline \multirow{2}{*}{ Job Satisfaction } & \multirow{2}{*}{0.249} & Constant & 2.722 & 0.089 & $30.730^{*}$ & $102.904 *$ \\
& & WLB & 0.270 & 0.027 & $10.144^{*}$ & ( \\
\hline
\end{tabular}

Note: ${ }^{*} \mathrm{p}<0.001$.

From a statistical point of view, the proposed model is significant $(p<0.001)$. According to the results of the regression analysis displayed on table 11 , an $\mathrm{R}^{2}$ value (percentage of explained variance), F statistic, $t$-value and the B value clearly reveal that WLB has a significant positive effect on job satisfaction. On the basis of this result, $\mathbf{H 2}$ is also accepted. The findings of the current study concurs with that of literature (Kanwar, et al., 2009; Saeed \& Farooqi, 2014; Mas-Machuca et al., 2016).

To determine the moderating role of WLB on the effect of job stress on job satisfaction, Hayes (2017: 220) moderation statistical method is employed. The moderation model and the results of the moderator analysis are shown below.

Job Satisfaction $=b_{0}+b_{1}$ Job Stress $+b_{2} W L B+b_{3}$ Job Stress $\times W L B+\varepsilon \ldots \ldots \ldots \ldots . . .3$

Table 12

Regression Results of Moderating Role of Work-Life Balance

\begin{tabular}{lccccccc}
\hline Dependent Variable & $\mathbf{R}^{\mathbf{2}}$ & Variables & B & Std. Error & t & F & P \\
\hline \multirow{3}{*}{ Job Satisfaction } & & Constant & 2.91 & 0.29 & $10.008^{*}$ & & 0.00 \\
& \multirow{3}{*}{0.31} & Job Stress & -0.06 & 0.09 & -0.59 & $44,91^{*}$ & 0.55 \\
& & WLB & 0.35 & 0.08 & $4.27^{*}$ & 0.00 \\
& & Job Stress $\times$ WLB & -0.03 & 0.03 & -1.12 & 0.26 \\
\hline
\end{tabular}

Note: ${ }^{*} \mathrm{p}<0.001$

As seen from Table 12 above, the overall model is significant $(\mathrm{p}<0.001)$. However, the interaction term (product of job stress and WLB) is found out not to be statistically significant. Its beta value of -0.03 , $t$-value of -1.12 and $p$-value of 0.26 clearly depict that the interaction effect is not statistically significant. This implies that the effect of job stress on job satisfaction does not depend on WLB. Hence, WLB does not have a moderating role on the effect of job stress on job satisfaction in this study. Based on this result, $\mathbf{H} 3$ is rejected. Therefore, no further investigation or probe of the interaction effect was conducted. 


\section{Conclusion and Managerial Implications of the Study}

The consequences that job stress poses on employees and organization in terms of its negative impact on productivity, effectiveness, safety, health, job satisfaction, among others call for high premium to be placed on it by creating congenial organizational climate and instituting workable stress management techniques so as to alleviate its ramifications. A good fit between employees' personal and professional lives having the propensity to affect their job satisfaction demands measures for enhancing WLB.

This study is conducted to determine the moderating role of WLB on the effect of job stress on job satisfaction of people working in manufacturing SMEs operating in Büsan Organized Industrial Zone in Konya, Turkey. In the descriptive analyses and evaluations, it is generally observed that the participants' level of job stress is moderate while their WLB and job satisfaction levels are a little above average. Based on the results of inferential statistical analyses, it is concluded that job stress has a statistically significant negative effect on employees' job satisfaction and weak negative relationship exists between them. In addition, the findings of this study reveal WLB having a statistically significant positive effect and relationship with job satisfaction. Furthermore, WLB is found not to have a moderating role on the effect of job stress on job satisfaction. This result implies that without WLB, job stress can influence or affect job satisfaction. In other words, the impact of job stress on job satisfaction is not dependent on WLB. Thus, the moderator (WLB) and the predictor variable (job stress) do not interact in their effect on the outcome variable (job satisfaction). In general, on the face of the empirical findings obtained, the first and second hypotheses are accepted and the third hypothesis is discarded. The reason may well be that job stress experienced by employees is such an intense feeling that once it is experienced it may not be irremediable in terms of job satisfaction even if the employees have found a balance between their work and life.

The findings of the study have relevant implications for policy makers of SMEs in their pursuit to increase employees' job satisfaction at workplace. On the premise of the above results, there is the need for policy makers/managers of SMEs to institute stress management techniques that could curtail the negative consequences of employees' job stress while maximizing its merits. Having a work environment that provide and encourage employees to practise or participate in measures such as physical exercise, outdoor activities, cognitive restructuring, hypnosis, relaxation, meditation and effective time management shall be a crucial option for organizations. Also, formulation of policies or strategies that will enable employees to have a good equilibrium between their work and personal lives are required. This could be realized through implementation of flexible work arrangements such as job sharing, part-time, telecommuting, flexible work hours, among others. In brief, the findings of this study will help create the awareness of managers and policy makers on the consequences of job stress and on the need to assist employees have a balance between their personal and professional lives thereby leading to job satisfaction. 


\section{Limitations}

It cannot be declared that the current study is free of certain limitations. This study is restricted to only spare parts manufacturing SMEs operating in Konya, Turkey. Hence, it is not clear to what degree one can generalize the findings of this study to other institutions across the country and elsewhere. Consequently, it is proposed that future researchers should focus on other kind of institutions in varying sectors. Besides, the current study did not make use of mediating variable(s) in the conceptual model but rather a moderating variable, it is therefore an avenue for future researchers to add other related variables and examine their effects on job satisfaction.

Peer-review: Externally peer-reviewed.

Conflict of Interest: The authors have no conflict of interest to declare.

Grant Support: The authors declared that this study has received no financial support.

\section{References}

Ahsan, N., Abdullah, Z., \& Fie, D. Y. G. (2009). A Study of Job Stress on Job Satisfaction among University Staff in Malaysia: Empirical Study. European Journal of Social Sciences, 8(1), 121-131.

Arasli, H., \& Tumer, M. (2008). Nepotism, Favoritism and Cronyism: A Study of their Effects on Job Stress and Job Satisfaction in the Banking Industry of North Cyprus. Social Behavior and Personality, 36(9), 1237-1250.

Armstrong, M. (2006). A Handbook of Human Resource Management Practice (10th ed.). London: Kogan Page Publishing.

Bell, A. S., Rajendran, D., \& Theiler, S. (2012). "Job Stress, Wellbeing, Work-Life Balance and Work-Life Conflict Among Australian Academics," E-Journal of Applied Psychology, 8(1): 25-37.

Bemana, S., Moradi, H., Ghasemi, M., Taghavi, S. M., \& Ghayoor, A. H. (2013). The relationship among job stress and job satisfaction in municipality personnel in Iran. World Applied Sciences Journal, 22(2), 233-238.

Bell, A. S., Rajendran, D., \& Theiler, S. (2012). Job Stress, Wellbeing, Work-Life Balance and Work-Life Conflict Among Australian Academics 8(1). E-Journal of Applied Psychology, 8(1), 25-37.

Casper, W. J., Vaziri, H., Wayne, J. H., DeHauw, S., \& Greenhaus, J. (2018). The jingle-jangle of work-nonwork balance: A comprehensive and meta-analytic review of its meaning and measurement. Journal of Applied Psychology, 103(2), 182-214.

Chen, P. S., Huang, C. Y., Yu, C. C., \& Hung, C. C. (2017). The examination of key performance indicators of warehouse operation systems based on detailed case studies. . Journal of Information and Optimization Sciences, 38, 367-389.

Clark, S. C. (2000). Work/family border theory: A new theory of work/ family balance. Human Relations, 53(6), 747-770.

Daehlen, M. (2008). Job satisfaction and job values among beginning nurses:A questionnaire survey. International Journal of Nursing Studies, 45(12), 1789-1799.

Deveci, B., \& Avcıkurt, C. (2017). The Effect of Work-Family Conflict and Work Stress on the Quality of Life: A Large Scaled Research on the Culinary Workers of Hotels. Journal of Academic Social Science, 5(40), 313-331. 
Dundas, K. (2008). Work-Life Balance: There is no "one-size-fits-all” solution. In K. O'Rourke (Ed.), Managing matters. New South Wales, U.K: Southern Cross University.

Efeoğlu, İ. E., \& Özgen, H. (2006). İş-Aile Yaşam Çatişmasinin İş Stresi, İş Doyumu Ve Örgütsel Bağlilik Üzerindeki Etkileri: İlaç Sektöründe Bir Araştirma (The Effects of Work Family Conflict on Job Stress, Job Satisfaction and Organisational Commitment: A Study in the Pharmaceutical Industry), Journal of Çukurova University Institute of Social Sciences, 16(2): 237-254.

Fairbrother, K., \& Warn, J. (2003). Workplace dimensions, stress and job satisfaction. Journal of Managerial Psychology, 18(1), 8-21.

Fisher, G. G. (2001). Work/personal life balance: A construct development study. Bowling Green State University, Bowling Green, $\mathrm{OH}$.

Friday, S. S., \& Friday, E. (2003). Racioethnic perceptions of job characteristics and job satisfaction. Journal of Management Development, 22(5), 426-442.

Goode, M., \& Moutinho, L. (1995). The effects of free banking on overall satisfaction: The use of automated teller machines. International Journal of Bank Marketing, 13(4), 168-190.

Goswami, I., \& Dsilva, N. R. (2019). Impact of job satisfaction and job stress on employees' life in Mumbai's hospitality sector. Journal of Strategy and Management. doi:10.1108/jsma-01-2019-0012

Greenhaus, J., Collins, K., \& Shaw, J. (2003). The relation between work-family balance and quality of life Journal of Vocational Behavior, 63(3), 510-531.

Hancer, M., \& George, R. T. (2003). Job satisfaction of restaurant employees: An empirical investigation using the Minnesota Satisfaction Questionnaire. Journal of Hospitality \& Tourism Research, 27(1), 85-100.

Hayes, A. F. (2017). Introduction to mediation, moderation, and conditional process analysis: A regressionbased approach (2nd ed.). New York, NY: Guilford Publications.

Hayman, J. (2005). Psychometric assessment of an instrument designed to measure work life balance. Research and practice in human resource management, 13(1), 85-91.

Hoffman, B. J., Blair, C. A., Maeriac, J. P., \& Woehr, D. J. (2007). Expanding the Criterion Domain? A Quantitative Review of the OCB Literature. Journal of Applied Psychology, 99(2), 555-566.

Hoppock, R. (1937). Job satisfaction of psychologists. Journal of Applied Psychology, 21(3), 300-303.

House, R. J., \& Rizzo, J. R. (1972). (1972). Role conflict and ambiguity as critical variables in a model of organizational behavior. Organizational behavior and human performance. 7(3), 467-505.

Hussain, K., Khan, A., \& Bavik, A. (2003). The effects of job performance on frontline employee job satisfaction and quitting intent: The case of hotels in Turkish Republic of Northern Cyprus. EMU Journal of Tourism Research, 4(1), 83-94.

Hussein, O., Njati, I. C., \& Rukangu, S. (2016). Influence of Work Life Balance on Employee Job Satisfaction: A Case of Northern Rangelands Trust in Isiolo County, Kenya. International Journal of Economics, Commerce and Management, IV(11), 443-457.

Jamal, M. (2005). Burnout among Canadian and Chinese employees: A cross-cultural study. European Management Review, 2, 224-230.

Judge, T. A., Thoresen, C. J., Bono, J. E., \& Patton, G. K. (2001). The job satisfaction-job performance relationship: A qualitative and quantitative review. Psychological bulletin, 127(3), 376-407.

Kalliath, T., \& Brough, P. (2008). Work-life balance: A review of the meaning of the balance construct. Journal of Management and Organization, 14(3), 323-327. doi:10.5172/jmo.837.14.3.323 
Kanwar, Y. P. S., Singh, A. K., \& Kodwani, A. D. (2009). Work-life balance and burnout as predictors of job satisfaction in the IT-ITES industry. Vision-The Journal of Business Perspective, 13(2), 1-12.

Karthik, R. (2013). A Study on Work-Life Balance in Chennai Port Trust, Chennai. Advances In Management, 6 (7), 26-31.

Kathirvel, N. (2009). A Study on Stress Among Employees Working in BPOS with Special Reference to Coimbatore The IUP Journal of Management Research, VIII(11), 28-44.

Kazmi, A. B., \& Singh, A. P. (2015). Work-life balance, stress, and coping strategies as determinants of job satisfaction among police personnel. Indian Journal of Health and Wellbeing, 6(12), 1244-1247.

Keleş, H. N., \& Fındıklı, M. A. (2016). The effect of the meaningfulness of work on job satisfaction, job stress and intention to leave. Global Journal of Business, Economics and Management: Current Issues, 6(2). doi:10.18844/gjbem.v6i2.1370

Kenworthy, J., Fay, C., Frame, M., \& Petree, R. (2014). A meta-analytic review of the relationship between emotional dissonance and emotional exhaustion. Journal of Applied Social Psychology(2), 94-105.

Kofodimos, J. R. (1993). Balancing act: How managers can integrate successful careers and fulfilling personal lives. San Francisco, CA, USA: Jossey-Bass.

Koh, H. C., \& Boo, E. H. Y. (2001). The Link Between Organizational Ethics and Job Satisfaction: A Study of Managers in Singapore. Journal of Business Ethics, 29(4), 309-324.

Leka, S., \& Griffiths, A. (2003). Work Organisation \& Stress: Systematic Problem Approaches for Employers, Managers and Trade Union Representatives. Geneva, Switzerland: World Health Organization.

Mamo, Y. (2014). the effect of work stress on employee job satisfaction of public organization: The case study of Nekemte city administration' (Masters Thesis), Wollega University,

Nekemte, Ethiopia.

Mas-Machuca, M., Berbegal-Mirabent, J., \& Alegre, I. (2016). Work-life balance and its relationship with organizational pride and job satisfaction. Journal of Managerial Psychology, 31(2), 586-602. doi:10.1108/ jmp-09-2014-0272

Mengenci, C. (2015). Who knows? Organizational culture might be the source of job satisfaction or stress: Evidence from Turkey. International Journal of Academic Research in Business and Social Sciences, 5(3), 514-524.

Page, K. M., \& Vella-Brodrick, D. (2009). The 'what', 'why' and 'how' of employee well-being: A new model. Social Indicators Research, 90(3), 441-448.

Parvin, M. M., \& Kabir, M. M. N. (2011). Factors Affecting Employee Job Satisfaction of Pharmaceutical Sector. Australian Journal of Business and Management Research, 1(9), 113-123.

Riketta, M. (2008). The causal relation between job attitudes and performance: A meta- analysis of panel studies. Journal of Applied Psychology, 93(2), 472-481.

Robbins, S. P., \& Judge, T. A. (2016). Organizational Behavior, Global Edition (17th ed.). Harlow, England: Pearson Education Limited.

Saari, L., \& Judge, T. A. (2004). Employee Attitudes and Job Satisfaction. Human Resource Management, $43(4), 395-407$.

Saeed, K., \& Farooqi, Y. A. (2014). Examining the relationship between work life balance, job stress, and job satisfaction among university teachers (A case of University of Gujarat). International Journal of multidisciplinary sciences and engineering, 5(6), 9-15. 
Scroggins, W. (2008). The relationship between employee fit perceptions, job performance, and retention: Implications of perceived fit. Employee Responsibilities \& Rights Journal, 20(1), 57-71.

Selye, H. (1973). The evolution of the stress concept. American Scientist, 61(6), 692-699.

Sirajunisa, K., \& Panchanatham, N. (2010). Influence of occupational stress on work life balance among women professionals. The Journal of Commerce, 2(1), 44-57.

Super, D. E. (1939). Occupational level and job satisfaction. Journal of Applied Psychology, 23(5), 547-564.

Tan, P. P., \& Hawkins, W. E. (2000). The factor structure of the Minnesota Satisfaction Questionnaire and participants of vocational rehabilitation. Psychological Reports, 87(1), 34-36.

Travers, C. J., \& Cooper, C. L. (1993). Mental health, job satisfaction and occupational stress among UK teachers. Work \& Stress, 7(3), 203-219. doi:10.1080/02678379308257062

Ueda, Y. (2012). The Relationship between Work-life Balance Programs and Employee Satisfaction: Gender Differences in the Moderating Effect of Annual Income. Journal of Business Administration Research, 1(1). doi:10.5430/jbar.v1n1p65

Weiss. (2002). Deconstructing job satisfaction Separating evaluations, beliefs and affective experiences. Human Resource Management Review, 12(2), 173-194.

Weiss, Dawis, R. V., \& England, G. W. (1967). Manual for the Minnesota satisfaction questionnaire. Minnesota studies in vocational rehabilitation.

Williams, E. S., Konrad, T. R., Scheckler, W. E., Pathman, D. E., Linzer, M., McMurray, J. E., . . S Schwartz, M. (2001). Understanding physicians' intentions to withdraw from practice: the role of job satisfaction, job stress, mental and physical health. Health Care Manage Review, 26(1), 7-19.

Yamane, T. (1967). Statistics, An Introductory Analysis (2nd ed.) New York: Harper and Row.

Yan, H., \& Xie, S. (2016). How does auditors' work stress affect audit quality? Empirical evidence from the Chinese stock market. China Journal of Accounting Research, 9(4), 305-319.

Yildirim, D., \& Aycan, Z. (2008). Nurses' work demands and work-family conflict: A questionnaire survey. International journal of nursing studies, 45(9), 1366-1378.

Yiu, T. W., \& Lee, H. K. (2011). How Do Personality Traits Affect Construction Dispute Negotiation: Study of Big Five Personality Model. Journal of Construction Engineering and Management, 137(3), 169-178. 